\title{
Six Times Weekly
}

National Cancer Institute

\section{Source}

National Cancer Institute. Six Times Weekly. NCI Thesaurus. Code C98857.

Six times per week. 